\title{
PROFIL MISKONSEPSI SISWA PADA MATERI PECAHAN BERDASARKAN TINGKAT KEMAMPUAN MATEMATIKA SISWA
}

\author{
Nurhamdiah ${ }^{1}$, Ahmad Nizar Rangkuti ${ }^{2}$ \\ ${ }^{1}$ Program Pasca Sarjana Pendidikan Matematika, FKIP, Universitas Riau \\ ${ }^{2}$ Program Studi Tadris Matematika, FTIK, IAIN Padangsidimpuan \\ e-mail: nurhamdiah6590@grad.unri.ac.id
}

\begin{abstract}
Elementary school sixth-grade students still experience misconceptions fractions causing low student mathematics learning outcomes. The purpose of this study is to find out the student's misconceptions in the fraction material. The type of research conducted is descriptive qualitative research. The subjects studied were 6 grade VI elementary school students, 2 subjects with high mathematical ability levels, 2 subjects with moderate mathematical ability levels, and 2 subjects with low mathematical ability levels. Data collection methods used were interviews and multiple-choice tests based on fraction material. The results of the study stated: (1) The students' dominant misconceptions in the concept of calculating fraction distribution operations. (2) Misconceptions experienced by students with high mathematical abilities are less than students with moderate and low mathematical abilities. With this research, the teacher can find out the students' misconceptions in the subject matter fractions and the teacher can be more maximal in teaching the concept of fractions.
\end{abstract}

Keywords: Misconception, Fraction Material, Mathematical Ability

\begin{abstract}
Abstrak
Siswa kelas VI SD masih mengalami miskonsepsi pada materi pecahan menyebabkan rendahnya hasil belajar matematika siswa. Tujuan dari penelitian ini adalah untuk mengetahui miskonsepsi siwa pada materi pecahan. Jenis penelitian yang dilakukan adalah penelitian kualitatif deskriptif. Subjek yang diteliti adalah 6 siswa kelas VI SD, 2 subjek dengan tingkat kemampuan matematika tinggi, 2 subjek dengan tingkat kemampuan matematika sedang, dan 2 subjek dengan tingkat kemampuan matematika rendah. Metode pengumpulan data yang digunakan yaitu wawancara dan tes pilihan ganda beralasan materi pecahan. Hasil Penelitian menyebutkan: (1) miskonsepsi siswa dominan pada konsep operasi hitung pembagian pecahan, (2) miskonsepsi yang dialami siswa dengan kemampuan matematika tinggi lebih sedikit jika dibandingkan siswa dengan kemampuan matematika sedang dan rendah. Dengan adanya penelitian ini, guru dapat mengetahui miskonsepsi siswa pada materi pokok pecahan dan guru dapat lebih maksimal dalam mengajarkan konsep pecahan.
\end{abstract}

Kata kunci: Miskonsepsi, Materi Pecahan, Kemampuan Matematika

\section{PENDAHULUAN}

Pecahan merupakan cabang dari aritmatika yang sangat erat kaitannya dengan kehidupan sehari-hari dan merupakan materi yang berhubungan dengan materi yang lain (Prasetyo, 2014). Pecahan adalah salah satu materi yang paling kompleks yang harus dipelajari anak selama di sekolah dasar ( Mamede dan Oliveira, 2011). Menurut Charalambous dan Pitta-Pantazi (2007); Kyriakides (2011) dalam mengajar dan belajar matematika, pecahan sudah lama dipandang sebagai salah satu konsep yang paling bermasalah di matematika sekolah dasar. 
Materi pecahan telah diberikan dan dipelajari oleh siswa, ketika mereka duduk di kelas III sampai kelas V. Pemahaman konsep pecahan yang telah dipelajari pada jenjang sebelumnya merupakan prasyarat untuk mempelajari konsep pecahan di kelas VI sehingga tidak terjadi miskonsepsi. Ibrahim (2012) menyatakan bahwa miskonsepsi adalah kesalahan konsep yang terjadi akibat seseorang yang tetap kembali ke konsep awal yang dimilikinya padahal orang tersebut telah diperkenalkan pada konsep yang benar.

Suparno (2005), Malikha dan Amir (2018), mendefenisikan miskonsepsi lebih mendetail, yaitu miskonsepsi sebagai pengertian yang tidak akurat akan konsep, penggunaan konsep yang salah, klasifikasi contoh-contoh yang salah, kekacauan konsep-konsep yang berbeda, dan hubungan hirarkis konsep-konsep yang tidak benar. Dari beberapa pengertian diatas dapat disimpulkan bahwa miskonsepsi adalah suatu pemahaman yang tidak akurat akan konsep, penggunaan konsep yang tidak sesuai dengan konsep yang telah disepakati secara ilmiah oleh pakar ahli dalam bidang tersebut, ketidak mampuan dalam menghubungkan konsep awal dengan konsep selanjutnya secara benar dan bersifat resisten atau sulit diubah.

Penelitian yang dilakukan oleh Sarlina menunjukkan bahwa masih terdapat miskonsepsi siswa pada soal materi persamaan kuadrat (Sarlina, 2015). Sejalan dengan Sarlina penelitian yang dilakukan Hasan (2015) menunjukkan bahwa terjadi miskonsepsi siswa pada bilangan bulat, hasil ini ditunjukkan dengan hasil tes siswa yang disertai Certainty of response index (CRI) dan hasil wawancara siswa yang mengalami miskonsepsi. Penelitian yang dilakukan Novia Edah dan Siti Maghfiratu (2017), menunjukkan bahwa miskonsepsi terjadi pada ketiga subjek yang memiliki tingkat kecerdasan logis-matematis berbeda (Edah dan Maghfiratu, 2017). Sejalan dengan Novia Edah dan Siti Maghfiratu (Malikha dan Amir, 2018) juga menyatakan bahwa masih terdapat miskonsepsi siswa pada materi pecahan berdasarkan tingkat kemampuan matematika siswa.

Berdasarkan pengamatan dan wawancara peneliti dengan beberapa guru SD, sebagian besar siswa mengalami kesulitan dalam memahami materi-materi matematika di sekolah dikarenakan kurangnya pemahaman siswa terhadap konsep bilangan beserta operasinya, khususnya materi pecahan. Adanya kesalahankesalahan yang dibuat oleh siswa pada saat mengerjakan soal mendorong peneliti untuk lebih mengetahui apakah kesalahan tersebut berasal dari ketidaktahuan konsep atau miskonsepsi.

\section{METODE PENELITIAN}

Jenis penelitian yang digunakan dalam penelitian ini adalah penelitian deskriptif kualitatif. Subjek penelitian adalah siswa kelas VI SD IT Sakinah. Subjek penelitian ditetapkan dengan rincian dua siswa yang berkemampuan matematika tinggi, dua siswa berkemampuan matematika sedang dan dua siswa berkemampuan matematika rendah. Penentuan kategori kemampuan matematika siswa didasarkan pada skor tes kemampuan awal matematika siswa. Dari 20 orang siswa terdapat 6 orang siswa dengan tingkat kemampuan matematika tinggi, 8 orang siswa kemampuan sedang dan 6 orang siswa dengan kemampuan rendah. Diambil 2 orang siswa perkategori kemampuan karena: pertama untuk mempermudah peneliti dalam menganalisis data, kedua pada tes kemampuan awal siswa dari beberapa kategori di atas mempunyai kesalahan yang sama dalam menyelesaikan soal tes kemampuan awal. 
Tahapan penelitian ini meliputi: Pemilihan Soal, pegumpulan data, dan analisis data dengan penjelasan berikut. Teknik pengumpulan data dalam penelitian ini adalah wawancara dan tes berupa soal tes pilihan ganda. Soal yang diteskan adalah soal Ujian Nasional (UN). Soal - soal UN yang diambil sebanyak 10 soal. Tahapan Analisis data yang dilakukan adalah reduksi data, penyajian data, dan menarik kesimpulan. Reduksi data yang dilakukan peneliti memilih siswa yang mengalami miskonsepsi dari hasil tes dengan mentabulasi jawaban siswa. Untuk mengetahui siswa yang mengalami miskonsepsi, maka siswa dikelompokkan terlebih dahulu berdasarkan hasil skor tes pilihan ganda. Selanjutnya penyajian data yang bertujuan untuk memudahkan peneliti dan pembaca dalam memahami apa yang terjadi. Penyajian data pada penelitian ini menggunakan teks yang bersifat naratif dengan bantuan gambar jawaban siswa.

\section{HASIL DAN PEMBAHASAN}

Data skor tes kemampuan matematika siswa diperoleh dari instrumen soal tes kemampuan awal matematika. Instrumen dibuat bertujuan untuk mengukur kemampuan matematika siswa kelas VI SDIT Sakinah. Setelah dilakukan tes kemampuan awal pada siswa kelas VI maka diambil 2 siswa dengan tingkat kemampuan marematika tinggi, 2 siswa dengan tingkat kemampuan matematika sedang dan 2 siswa dengan tingkat kemampuan matematika rendah. Adapun rincian masing-masing subjek penelitian yang terpilih, disajikan pada gambar 1 .

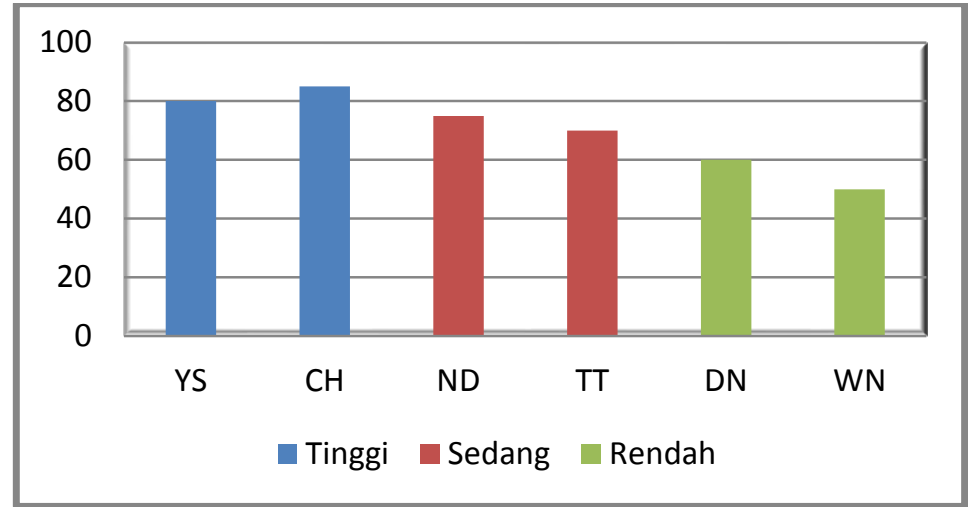

Gambar 1. Daftar Subjek Penelitian

Subjek yang terdapat pada gambar 1, diberikan soal tes pilihan berganda tentang materi pecahan. Dari 20 siswa diambil 6 siswa yang mengalami miskonsepsi. Keenam siswa pada gambar 1 adalah siswa yang dipilih berdasarkan tingkat kemampuan matematika dimana terdapat 2 siswa yang memiliki nilai 80 dan 85 yang temasuk kepada kemampuan metematika tinggi, 2 siswa mendapatkan nilai 70 dan 75 dan dikategorikan kepada kemampuan matematika sedang dan 2 siswa mendapatkan nilai 60 dan 50 dikategorikan kepada kemampuan matematika rendah . Dari 6 siswa tersebut diperoleh data miskonsepsi sebanyak 7 soal dari total 10 soal yang diberikan. Hampir semua siswa mengalami miskonsepsi pada soal yang bervariasi. Mulai dari konsep mengubah bentuk pecahan, mengurutkan pecahan sampai operasi hitung campuran pecahan. Dipilih dua soal untuk dianalisis, dua soal tersebut dipilih berdasarkan miskonsepsi yang dialami keenam subjek. Adapun data rincian soal miskonsepsi siswa kelas VI dapat dilihat pada tabel 1. 
Tabel 1. Rincian soal miskonsepsi

\begin{tabular}{|c|l|l|}
\hline No Soal & \multicolumn{1}{|c|}{ Soal } & \multicolumn{1}{c|}{ Konsep } \\
\hline $\mathbf{7}$ & $\begin{array}{l}\text { Hasil dari } 5 \frac{4}{5}-\frac{3}{4}+\frac{3}{8} \\
\text { adalah . . . }\end{array}$ & $\begin{array}{l}\text { Operasi hitung penjumlahan } \\
\text { dan pengurangan pecahan. }\end{array}$ \\
\hline $\mathbf{1 0}$ & $\begin{array}{l}\text { Hasil dari } 75 \% \times 2,8: \frac{3}{5} \\
\text { adalah . . . }\end{array}$ & $\begin{array}{l}\text { Operasi hitung perkalian } \\
\text { dan pembagian pecahan. }\end{array}$ \\
\hline
\end{tabular}

Adapun penjelasan miskonsepsi yang terjadi pada siswa dengan tingkat kemampuan matematika tinggi, tingkat kemampuan matematika sedang dan tingkat kemampuan matematika rendah sebagai berikut:

1. YS (Siswa dengan tingkat kemampuan matematika tinggi).

Adapun bentuk miskonsepsi siswa YS adalah sebagai berikut:

$$
\begin{aligned}
\frac{29}{5}-\frac{3}{4}+\frac{3}{8} & =\frac{4 \times 29}{5 \times 4}-\frac{3 \times 5}{4 \times 5}+\frac{3}{8}=\frac{116}{20}-\frac{15}{20}+\frac{3}{8} \\
& =\frac{101}{20}+\frac{58}{80} \frac{3}{8}=\frac{101 \times 8}{20 \times 8}+\frac{3 \times 20}{8 \times 20} \\
& =\frac{800}{160}+\frac{60}{160}=\frac{860}{160}: \frac{2}{2}=\frac{434}{80}: \frac{2}{2}=5 \frac{17}{40}
\end{aligned}
$$

\section{Gambar 2. Cuplikan Jawaban YS pada Soal Tes Nomor 7}

Jawaban YS seperti disajikan pada gambar 1, untuk mencari hasil penjumlahan dan pengurangan pecahan dengan cara mengubah pecahan yang berbentuk pecahan campuran menjadi bentuk pecahan biasa. Setelah pecahan diubah kedalam bentuk pecahan biasa, YS menyamakan penyebut pecahan tersebut dengan cara mengali silang. YS mengalami miskonsepsi karena YS beranggapan untuk menyamakan penyebut dari pecahan tersebut harus dikali silang. Berdasarkan wawancara yang dilakukan peneliti dengan subjek YS, YS mengatakan cara yang digunakan untuk mencari penjumlahan dan pengurangan pecahan tersebut diperoleh dari guru yang mengajarkan pelajaran matematika di kelas, padahal konsep tersebut bukan termasuk konsep ilmiah meskipun pada dasarnya hasilnya benar.

Menurut Adinawan, dkk (2007) untuk menyelesaikan penjumlahan dan pengurangan pecahan seharusnya dicari terlebih dahulu KPK dari penyebutnya agar penyebutnya menjadi sama, kemudian dicari pembilang dari pecahan - pecahan tersebut selanjutnya dijumlahkan atau dikurangkan. Sebagaimana dikemukakan oleh Liliawati (2008), terdapat beberapa hal yang dapat menyebabkan terjadinya miskonsepsi, salah satunya adalah metode mengajar dimana miskonsepsi dapat terjadi karena pengungkapan aplikasi yang salah dari konsep yang bersangkutan sehingga mengakibatkan miskonsepsi. Kesalahan yang dilakukan oleh YS juga dialami oleh siswa pada jenjang SMP sebagaimana yang terdapat pada penelitian Maria Endah, dkk (2016) bahwa siswa dalam menyelesaikan penjumlahan dan pengurangan pecahan dengan cara mengali silang penyebut dan pembilang pecahan.

Pada jawaban YS seperti disajikan pada gambar 3, untuk mencari hasil dari soal no 10 dengan cara mengubah pecahan - pecahan tersebut menjadi bentuk pecahan biasa. YS menyelesaikan perkalian pecahan terlebih dahulu dengan cara 
mengalikan pembilang dengan pembilang dan penyebut dengan penyebut. Selanjutnya YS menyelesaikan pembagian dengan cara yang sama seperti pada perkalian yaitu membagikan pembilang dengan pembilang dan penyebut dengan penyebut. Berdasarkan wawancara yang dilakukan peneliti dengan subjek YS, YS mengatakan bahwa dalam menyelesaikan pembagian pecahan sama halnya dengan menyelesaikan perkalian pecahan.

$$
\begin{aligned}
\frac{15}{100} \times \frac{28}{10}: \frac{3}{5} & =\frac{3}{4} \times \frac{14}{5}: \frac{3}{5}=\frac{42}{20}: \frac{3}{5} \\
& =\frac{14}{4}=3 \frac{1}{2}
\end{aligned}
$$

Gambar 3. Cuplikan Jawaban YS pada Soal Nomor 10.

Pada jawaban YS seperti disajikan pada gambar 3, untuk mencari hasil dari soal no 10 dengan cara mengubah pecahan - pecahan tersebut menjadi bentuk pecahan biasa. YS menyelesaikan perkalian pecahan terlebih dahulu dengan cara mengalikan pembilang dengan pembilang dan penyebut dengan penyebut. Selanjutnya YS menyelesaikan pembagian dengan cara yang sama seperti pada perkalian yaitu membagikan pembilang dengan pembilang dan penyebut dengan penyebut. Berdasarkan wawancara yang dilakukan peneliti dengan subjek YS, YS mengatakan bahwa dalam menyelesaikan pembagian pecahan sama halnya dengan menyelesaikan perkalian pecahan.

YS beranggapan perkalian sama dengan pembagian seperti penjumlahan sama dengan pengurangan. Disinilah yang menjadi letak miskonsepsi siswa. Kemungkinan penyebab terjadinya miskonsepsi ini dikarenakan siswa yang kurang mampu dalam mempelajari matematika sehingga menemukan kesulitan dalam memahami konsep yang benar. Berg (Sa'idah, 2011) mendefinisikan miskonsepsi sebagai pertentangan atau ketidakcocokan konsep yang dipahami seseorang dengan konsep yang dipakai oleh pakar ilmuwan yang bersangkutan. Kesalahan subjek YS juga dilakukan oleh salah satu siswa SMP. Sebagaimana penelitian yang dilakukan oleh Siti Ulfah dan Harina Fitriyani (2017) siswa menganggap bahwa operasi pembagian pada pecahan dapat diselesaikan dengan cara membagi langsung masingmasing bilangannya.

2. $\mathrm{CH}$ (Siswa dengan tingkat kemampuan matematika tinggi )

Adapun bentuk miskonsepsi siswa $\mathrm{CH}$ adalah sebagai berikut:

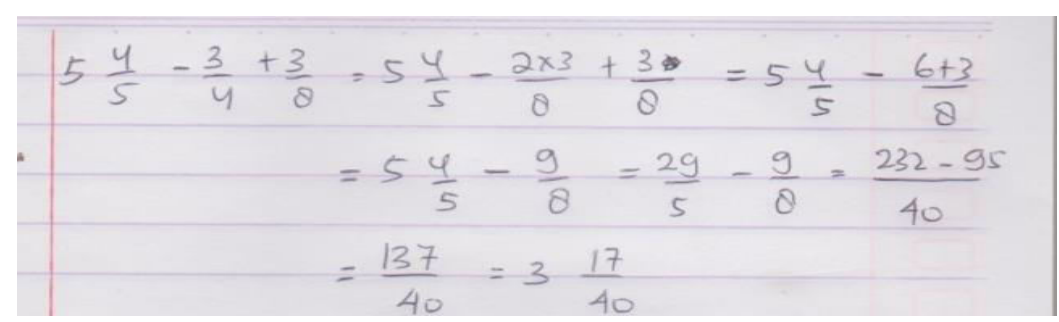

Gambar 4. Cuplikan Jawaban CH pada Soal Nomor 7.

Jawaban subjek $\mathrm{CH}$ disajikan pada gambar 4, dilihat dari gambar 3 untuk mencari hasil dari soal nomor $7 \mathrm{CH}$ menyelesaikan penjumlahan terlebih dahulu 
dengan mencari KPK dari dua pecahan tersebut kemudian dijumlahkan, selanjutnya $\mathrm{CH}$ mengubah pecahan campuran menjadi pecahan biasa dan mencari KPK dari kedua pecahan dan mencari hasilnya. Dari hasil wawancara yang dilakukan peneliti dengan subjek $\mathrm{CH}, \mathrm{CH}$ mengatakan jika ada dua operasi hitung penjumlahan dan pengurangan maka diselesaikan penjumlahan terlebih dahulu. Disinilah yang menjadi letak miskonsepsi siswa CH. Menurut Gunanto dan Dhesi Adhelia (2018) untuk menyelesaikan operasi hitung campuran penjumlahan dan pengurangan pada pecahan, pengerjaannya dilakukan urut dari kiri.

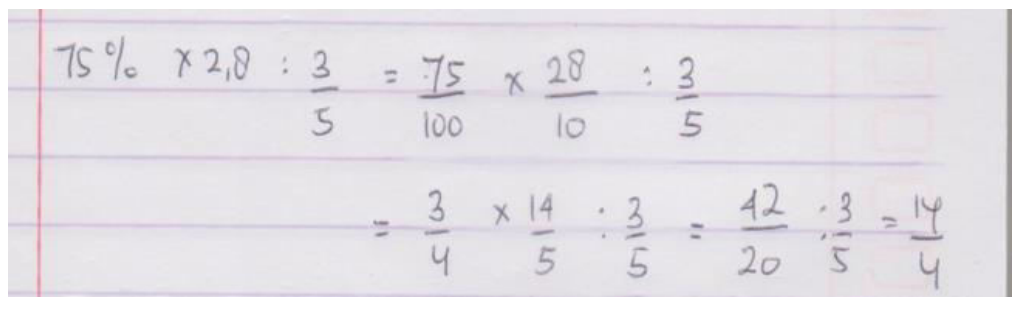

Gambar 5. Cuplikan Jawaban CH pada Soal Nomor 10.

Jawaban $\mathrm{CH}$ seperti disajikan pada gambar 5, untuk mencari hasil dari soal nomor 10 dengan cara mengubah pecahan - pecahan tersebut menjadi bentuk pecahan biasa. $\mathrm{CH}$ menyelesaikan perkalian pecahan terlebih dahulu dengan cara mengalikan pembilang dengan pembilang dan penyebut dengan penyebut. Selanjutnya $\mathrm{CH}$ menyelesaikan pembagian dengan cara yang sama seperti pada perkalian yaitu membagikan pembilang dengan pembilang dan penyebut degan penyebut. Berdasarkan wawancara yang dilakukan peneliti dengan subjek $\mathrm{CH}, \mathrm{CH}$ mengatakan bahwa dalam menyelesaikan pembagian pecahan sama halnya dengan menyelesaikan perkalian pecahan. $\mathrm{CH}$ beranggapan perkalian sama dengan pembagian seperti penjumlahan sama dengan pengurangan. Disinilah yang menjadi letak miskonsepsi siswa. Kemungkinan penyebab terjadinya miskonsepsi ini dikarenakan siswa yang kurang mampu dalam mempelajari matematika sehingga menemukan kesulitan dalam memahami konsep yang benar.

Berg (Sa'idah, 2011) mendefinisikan miskonsepsi sebagai pertentangan atau ketidakcocokan konsep yang dipahami seseorang dengan konsep yang dipakai oleh pakar ilmuwan yang bersangkutan. Kesalahan subjek $\mathrm{CH}$ juga dilakukan oleh salah satu siswa SMP. Sebagaimana penelitian yang dilakukan oleh Siti Ulfah dan Harina Fitriyani (2017) siswa menganggap bahwa operasi pembagian pada pecahan dapat diselesaikan dengan cara membagi langsung masing-masing bilangannya.

3. TT (Siswa dengan tingkat kemampuan matematika sedang )

Pada penelitian ini, dapat diketahui bahwa miskonsepsi yang dialami oleh TT dapat dilihat pada gambar 6 .

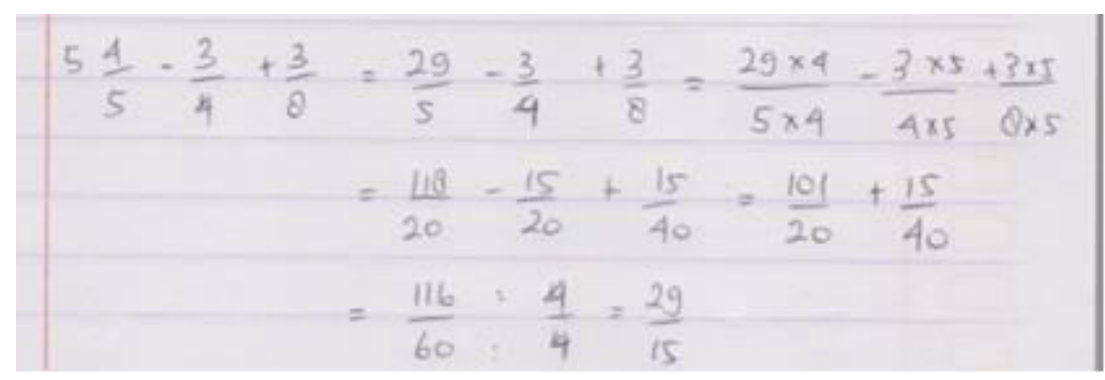

Gambar 6. Cuplikan Jawaban TT Soal Nomor 7. 
Berdasarkan gambar 6, menurut TT untuk mencari hasil dari soal nomor 7 dengan cara mengubah pecahan - pecahan tersebut menjadi bentuk pecahan biasa. Kemudian TT mengali silang untuk menyamakan penyebut pecahan. TT mengalami miskonsepsi karena TT berang-gapan untuk menyamakan penyebut dari pecahan tersebut harus dikali silang. Menurut Adinawan, dkk (2007) untuk menyelesaikan penjumlahan dan pengurangan pecahan seharusnya dicari terlebih dahulu KPK dari penyebutnya agar penyebutnya menjadi sama, kemudian dicari pembilang dari pecahan - pecahan tersebut selanjutnya dijumlahkan atau dikurangkan. Hasil wawancara yang dilakukan peneliti dengan subjek TT, cara yang digunakan untuk mencari penjumlahan dan pengurangan pecahan tersebut diperoleh dari guru yang mengajarkan pelajaran matematika di kelas, padahal konsep tersebut bukan termasuk konsep ilmiah meskipun pada dasarnya hasilnya benar. Sebagaimana dikemukakan oleh Liliawati (2008), terdapat beberapa hal yang dapat menyebabkan terjadinya miskonsepsi, salah satunya adalah metode mengajar dimana miskonsepsi dapat terjadi karena pengungkapan aplikasi yang salah dari konsep yang bersangkutan sehingga mengakibatkan miskonsepsi.

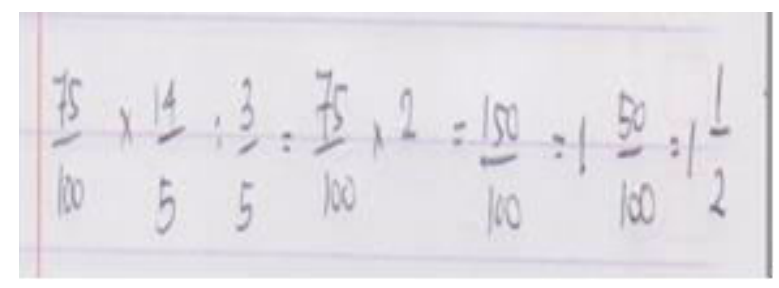

Gambar 7. Cuplikan Jawaban TT Soal Nomor 10.

Berdasarkan gambar 7, menurut TT untuk mencari hasil dari soal nomor 10 dengan cara mengubah pecahan - pecahan tersebut menjadi bentuk pecahan biasa. Kemudin TT menyelesaikan pembagian terlebih dahulu dengan cara membagikan pembilang dengan pembilang dan penyebut dengan penyebut, setelah hasilnya ditemukan TT langsung mengalikan. TT mengalami miskonsepsi karena TT melakukan operasi hitung pembagian terlebih dahulu tanpa melihat urut dari kedua operasi. Disinilah letak miskonsepsi siswa TT. Menurut Gunanto dan Dhesi (2018), operasi perkalian dan pembagian kedudukannya sama, jika operasi perkalian dan pembagian muncul maka pengerjaanya urut dari kiri.

4. ND (Siswa dengan tingkat kemampuan matematika sedang)

Pada penelitian ini, dapat diketahui bahwa miskonsepsi yang dialami oleh ND dapat dilihat pada gambar 8 .

$$
\begin{aligned}
5 \frac{4}{5}-\frac{3}{4}+\frac{3}{8} & =\frac{29}{5}-\frac{3}{4}+\frac{3}{8}=\frac{29}{5}-\frac{3 \times 8}{4 \times 8}+\frac{3 \times 4}{4 \times 8} \\
& =\frac{29}{5}-\frac{24}{32}+\frac{12}{32}=\frac{29}{5}-\frac{36}{32} \\
& =\frac{29 \times 32}{5 \times 32}-\frac{36 \times 5}{32 \times 5}=\frac{520}{160}-\frac{180}{160} \\
& =\frac{744}{160}: \frac{2}{2}=\frac{3 \times 4}{80}: \frac{2}{2}=\frac{187}{40} .
\end{aligned}
$$

Gambar 8. Cuplikan Jawaban ND Soal Nomor 7.

Jawaban subjek ND disajikan pada gambar 8 , dilihat dari gambar 8 untuk mencari hasil dari soal nomor 7 ND menyelesaikan penjumlahan terlebih dahulu 
dengan mengeali silang dari dua pecahan tersebut kemudian dijumlahkan, selanjutnya ND mengubah pecahan campuran menjadi pecahan biasa dan menyamakan penyebutnya dengan mengali silang. Dari hasil wawancara yang dilakukan peneliti dengan subjek ND, ND mengatakan jika ada dua operasi hitung penjumlahan dan pengurangan maka diselesaikan penjumlahan terlebih dahulu dan kemudian untuk menyamkan penyebutnya dengan cara dikali silang. Disinilah yang menjadi letak miskonsepsi siswa ND. Menurut Adinawan, dkk (2007) untuk menyelesaikan penjumlahan dan penguragnan pecahan seharusnya dicari terlebih dahulu KPK. Menurut Gunanto dan Desi Adelia (2018) untuk menyelesaikan operasi hitung campuran penjumlahan dan pengurangan pada pecahan, pengerjaannya dilakukan urut dari kiri.

$$
\begin{aligned}
\frac{75}{100} \times \frac{28}{10}: \frac{3}{5} & =\frac{3}{4} \times \frac{7 / 4}{5}: \frac{3}{5}=\frac{3}{1} \times \frac{7}{5}: \frac{3}{5} \\
& =\frac{21}{5}: \frac{3}{5}=\frac{7}{5}
\end{aligned}
$$

Gambar 9. Cuplikan Jawaban ND Soal Nomor 10.

Berdasarkan gambar 9, menurut ND untuk mencari hasil dari soal nomor 10 dengan cara mengubah pecahan - pecahan tersebut menjadi bentuk pecahan biasa. Kemudian ND menyelesaikan perkalian terlebih dahulu, setelah hasilnya ditemukan ND langsung membagikan dengan soal selanjutnya. ND mengalami miskonsepsi karena ND langsung membagikan pembilang dengan pembilang dan penyebut dengan penyebut. Disinilah letak miskonsepsi siswa ND. Berdasarkan wawancara yang dilakukan peneliti dengan ND, ND mengatakan bahwa operasi pembagian sama halnya dengan operasi pembagian pada bilangan bulat. Penyebab terjadinya miskonsepsi ini dikarenakan siswa yang kurang mampu dalam mempelajari matematika sehingga menemukan kesulitan dalam memahami konsep yang benar. Berg (Sa'idah, 2011) mendefinisikan miskonsepsi sebagai pertentangan atau ketidakcocokan konsep yang dipahami seseorang dengan konsep yang dipakai oleh pakar ilmuwan yang bersangkutan.

5. WN (Siswa dengan tingkat kemampuan matematika rendah )

Pada penelitian ini, dapat diketahui bahwa miskonsepsi yang dialami oleh WN dapat dilihat pada gambar 10 .

$$
5 \frac{4}{5}-\frac{3}{4}+\frac{2}{8}=5 \frac{1}{1}+\frac{3}{8}=5 \frac{7}{9}
$$

Gambar 10. Cuplikan Jawaban WN Soal Nomor 7.

Menurut WN untuk mencari hasil dari soal nomor 7 yaitu mengoperasikan pecahan tanpa memperhatikan apakah penyebutnya sama. WN mengurangkan langsung pecahan pertama dengan pecahan kedua dan menjumlahkan hasilnya dengan pecahan yang ketiga. Berdasarkan wawancara yang dilakukan peneliti dengan WN, WN mengatakan bahwa dalam menyelsaikan soal nomor 7 langsung dioperasikan tanpa memperhatikan bentuk pecahannya sama atau penyebutnya sama. Dari hasil jawaban tertulis dan wawancara, maka WN disimpulkan mengalami miskonsepsi. Menurut Ibrahim (2012) miskonsepsi adalah kesalahan konsep yang terjadi akibat seseorang yang tetap kembali ke konsep awal yang dimilikinya padahal 
orang tersebut telah diperkenalkan pada konsep yang benar. Kesalahan seperti gambar 9 juga terjadi pada siswa SMP, sebagaimana yang terdapat pada penelitian Hakim, Halini, Ahmad Yani T (2017) siswa menganggap bahwa operasi penjumlahan pada pecahan dapat diselesaikan dengan cara menjumlahkan langsung masing-masing bilangannya.

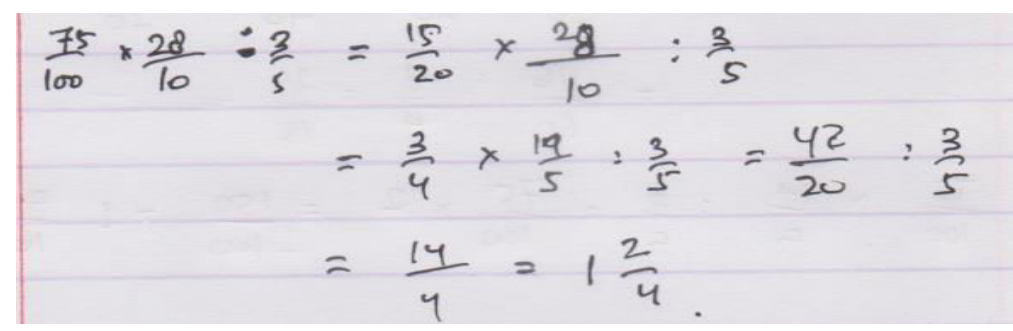

Gambar 11. Cuplikan Jawaban WN Soal Nomor 10.

Berdasarkan gambar 11, menurut WN untuk mencari hasil dari soal nomor 10 dengan cara mengubah pecahan - pecahan tersebut menjadi bentuk pecahan biasa. Kemudian WN menyelesaikan perkalian terlebih dahulu, setelah hasilnya ditemukan WN langsung membagikan dengan soal selanjutnya. WN mengalami miskonsepsi karena WN langsung membagikan pembilang dengan pembilang dan penyebut dengan penyebut. Disinilah letak miskonsepsi siswa WN. Berdasarkan wawancara yang dilakukan peneliti dengan $\mathrm{WN}$, WN mengatakan bahwa operasi pembagian sama halnya dengan operasi pembagian pada bilangan bulat. Penyebab terjadinya miskonsepsi ini dikarenakan siswa yang kurang mampu dalam mempelajari matematika sehingga menemukan kesulitan dalam memahami konsep yang benar. Berg (Sa'idah, 2011) mendefinisikan miskonsepsi sebagai pertentangan atau ketidakcocokan konsep yang dipahami seseorang dengan konsep yang dipakai oleh pakar ilmuwan yang bersangkutan.

6. DL (Siswa dengan tingkat kemampuan matematika rendah )

Pada penelitian ini, dapat diketahui miskonsepsi yang dialami oleh DL yaitu:

$$
\begin{aligned}
5 \frac{4}{5}-\frac{3}{4}+\frac{3}{8} & =\frac{25}{5}-\frac{3}{4}+\frac{3}{8}=\frac{25}{5}-\frac{3}{4}+\frac{3}{8} \\
& =\frac{22}{1}+\frac{3}{8}=\frac{25}{9}
\end{aligned}
$$

\section{Gambar 12. Cuplikan Jawaban DL Soal Nomor 7}

Menurut DL untuk mencari hasil dari soal nomor 7 yaitu mengoperasikan pecahan tanpa memperhatikan apakah penyebutnya sama. DL mengurangkan langsung pecahan pertam dengan pecahan kedua dan menjumlahkan hasilnya dengan pecahan yang ketiga. Berdasarkan wawancara yang dilakukan peneliti dengan DL, DL mengatakan bahwa dalam menyelesaikan soal nomor 7 langsung dioperasikan tanpa memperhatikan bentuk pecahannya sama atau penyebutnya sama. Dari hasil jawaban tertulis dan wawancara, maka DL disimpulkan mengalami miskonsepsi. Menurut Ibrahim (2012) miskonsepsi adalah kesalahan konsep yang terjadi akibat seseorang yang tetap kembali ke konsep awal yang dimilikinya padahal orang tersebut telah diperkenalkan pada konsep yang benar. Kesalahan seperti gambar 12 
juga terjadi pada siswa SMP, sebagaimana yang terdapat pada penelitian Hakim, dkk (2017) siswa menganggap bahwa operasi penjumlahan pada pecahan dapat diselesaikan dengan cara menjumlahkan langsung masing-masing bilangannya.

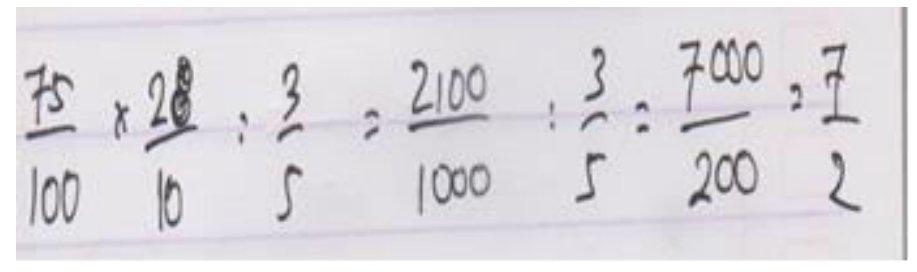

Gambar 13. Cuplikan Jawaban DL Soal Nomor 10

Berdasarkan gambar 12, menurut DL untuk mencari hasil dari soal nomor 10 dengan cara mengubah pecahan - pecahan tersebut menjadi bentuk pecahan biasa. Kemudian DL menyelesaikan perkalian terlebih dahulu, setelah hasilnya ditemukan DL langsung membagikan dengan soal selanjutnya. DL mengalami miskonsepsi karena DL langsung membagikan pembilang dengan pembilang dan penyebut dengan penyebut. Disinilah letak miskonsepsi siswa DL. Berdasarkan wawancara yang dilakukan peneliti dengan DL, DL mengatakan bahwa operasi pembagian sama halnya dengan operasi pembagian pada bilangan bulat.

Penyebab terjadinya miskonsepsi ini dikarenakan siswa yang kurang mampu dalam mempelajari matematika sehingga menemukan kesulitan dalam memahami konsep yang benar. Berg (Sa'idah, 2011) mendefinisikan miskonsepsi sebagai pertentangan atau ketidakcocokan konsep yang dipahami seseorang dengan konsep yang dipakai oleh pakar ilmuwan yang bersangkutan.

\section{KESIMPULAN}

Hasil penelitian ini menunjukkan bahwa siswa dengan tingkat kemampuan matematika tinggi, sedang dan rendah mengalami miskonsepsi yang sama pada pembagian pecahan. Siswa dengan kemampuan matematika tinggi mengalami miskonsepsi lebih sedikit. Siswa dengan tingkat kemampuan matematika sedang mengalami miskonsepsi yang sama dengan siswa yang memiliki tingkat kemampuan matematika tinggi. Siswa dengan tingkat kemampuan matematika rendah mengalami miskonsepsi lebih banyak dibandingkan dengan siswa yang memiliki kemampuan matematika tinggi dan sedang. Hasil penelitian ini dapat menjadi landasan bagi guru agar lebih maksimal dalam mengajarkan konsep pecahan.

\section{DAFTAR PUSTAKA}

Adinawan, Cholik dan Sugijono. 2007. Matematika SMP Jilid 1A Kelas VII Berdasarkan Standar Isi 2006. Jakarta: Erlangga.

Charalambous dan Pitta-Pantazi. 2007. Drawing on a Theoretical Model To Study Students' Understandings of Fractions. Educational Studies in Mathematics, (Online), 64: 293-316.

Edah, Noviah dan Siti Maghfiratun, 2017. Profil Miskonsepsi siswa pada Materi Bilangan Bulat Berdasarkan Tingkat Kecerdasan Logis - Matematis siswa. Mathemdunesa. Vol.2 No.6, pp 311-319.

Gunanto dan Dhesy Adhalia. 20018. Matematika untuk SD/MI Kelas VI Kurikulum 2013 Revisi. Jakarta: PT. Gelora Aksara Pratama. 
Hakim, Maida Sujana, Halini, Ahmad Yani T. 2017. Miskonsepsi Siswa Pada Materi Pecahan di Kelas VIII SMP LKIA Pontianak. Jurnal Elektronik FKIP UNTAN, tidak diterbitkan.

Hasan, Febiyanti R. 2015. Identifikasi Miskonsepsi Siswa Pada Materi Bilangan Bulat Menggunakan Certainty of Response Index (CRI).

Ibrahim, Muslimin. 2012. Konsep, Miskonsepsi, dan Cara Pembelajarannya. Surabaya: Unesa University Press.

Kyriakides, Andreas O. 2011. Questioning Assumptions That Limit The Learning of Fractions: The Story of Two Fifth Graders. Proceedings of The Seventh Congress of The European Society For Research in Mathematics Eduaction.

Liliawati, Winny dan Taufik Ramlan. 2009. Identifikasi Miskonsepsi Materi IPBA Di SMA Dengan Menggunakan Certainty of Response Index (CRI) Dalam Upaya Perbaikan Urutan Pemberian Materi IPBA Pada KTSP. Prosiding Seminar Nasional Penelitian, Pendidikan, dan Penerapan MIPA Fakultas MIPA, Universitas Negeri Yogyakarta.

Malikha dan Amir, 2018. Analisis Miskonsepsi Siswa Kelas V-B MIN Buduran Sidoarjo Pada Materi Pecahan Ditinjau Dari Kemampuan Matematika. Mathematics Education Journal. Vol 1 No.2, pp 75-81.

Mamede, Ema dan Oliveira. 2011. Issues on Children's Ideas of Fraction When Quotient Interpretation is Used. Proceedings of The Seventh Congress of The European Society For Research in Mathematics Education.

Prasetyorini, Nanda. 2013. "Profil Miskonsepsi Siswa Pada Materi Pokok Pecahan ditinjau Dari Kemampuan Matematika Siswa", Jurusan Matematika, FMIPA Unesa : Jurnal MATHEdunesa Vol 2, No 1 ISSN: 2301 9085

Savitri, Maria Endah. 2016. Analisis Miskonsepsi Siswa Pada Materi Pecahan Dalam Bentuk Aljabar Ditinjau dari Gaya Kognitif Siswa Kelas VIII di SMP NEGERI 2 Adimulyo Kabupaten KEBUMEN Tahun Ajaran 2013/2014. Jurnal Elektronik Pembelajaran Matematika Vol.4, No.4, pp 401 -413.

Sa'idah, Ghoniyatus. 2011. Penerapan startegi Pembelajaran PDEODE (PredictDiscuss-ExplainObserve-Discuss-explain) Untuk Merduksi Miskonsepsi Siswa pada Materi Hidrolisis Garam di SMA Negeri 2 Bojonegoro. Skripsi. Surabaya: Universitas Negeri Surabaya

Sarlina, 2015. Miskonsepsi Siswa Terhadap Pemahaman Konsep Matematika Pada Pokok Bahasan Persamaan Kudrat Siswa Kela X-5 SMA NEGERI 11 MAKASSAR. MaPan : Jurnal Matematika dan Pembelajaran p-ISSN: 23546883 ; e-ISSN: 2581-172X Volume 3, Nomor 2, pp 194 -209.

Suparno, Paul. 2005. Miskonsepsi \& Perubahan Konsep Pendidikan Fisika. Jakarta : Penerbit Grasindo.

Ulfah, Siti dan Harina Fitriyani, 2017. CERTAINTY OF RESPONSE INDEX (CRI): Miskonsepsi Siswa SMP pada Materi Pecahan. Seminar Nasional Pendidikan, Sains dan Teknologi Fakultas Matematika dan Ilmu Pengetahuan Alam Universitas Muhammadiyah Semarang. 